Proc. Estonian Acad. Sci. Geol., 2000, 49, 4, 251-266

\title{
ALTERATION OF ZIRCON AND GARNET DUE TO LOW-PRESSURE SHOCK AT THE KÄRDLA CRATER, ESTONIA
}

\author{
Mare KONSA ${ }^{\mathrm{a}}$, Anne KLEESMENT ${ }^{\mathrm{a}}$, and Väino PUURA ${ }^{\mathrm{b}}$
}

\author{
a Institute of Geology, Tallinn Technical University, Estonia pst. 7, 10143 Tallinn, Estonia; \\ kleesmen@gi.ee \\ b Institute of Geology, University of Tartu, Vanemuise 46, 51014 Tartu, Estonia; puura@ut.ee
}

Received 10 November 1999, in revised form 31 July 2000

\begin{abstract}
Immersion analysis with the polarizing microscope and SEM studies revealed fracturing in zircon and garnet grains from impact breccias of the Kärdla crater. The zircon grains showed impact-related features, including widening of pre-existing fractures in the internal zones, some fresh fractures, loss of inclusions, decrease in transparency, increase in turbidity, and the intensely cracked outermost coat in zoned zircons. The garnet grains were intensely fractured only in the uppermost subcrater basement, especially in allochthonous suevitic breccias. Zircon and garnet grains from different parts of the crater can serve as useful indicators of low shock pressure $(<8 \mathrm{GPa})$.
\end{abstract}

Key words: impact craters, shock metamorphism, impact breccia, typology, zircon, garnet, Kärdla crater, Estonia.

\section{INTRODUCTION}

The Middle Ordovician (455 Ma) Kärdla crater is a very specific feature in bedrock geology of Estonia (Puura \& Suuroja 1992; Koppelmaa et al. 1996). Its impact origin and related geophysical, structural, lithological, and geochemical features have been discussed in a number of publications (Puura \& Suuroja 1992; Plado et al. 1996; Puura et al. 1996, 2000). Rock and mineral clasts with planar deformation features (PDFs) are rare and met only in allochthonous suevitic breccias (Suuroja 1999). Consequently, the bulk of impact-deformed rocks forming the autochthonous and allochthonous breccias of the crater was subjected only to low-pressure shock. The present study focuses on traces of deformation of accessory zircon and garnet in these rocks. The fracturing and other changes in the shocked mineral grains are compared to those of the grains from unshocked rocks, based on a large sample set and the experience of long-time systematic mineralogical studies (Fig. 1; Konsa 1986, 1987; Puura et al. 2000). Our aim is to 

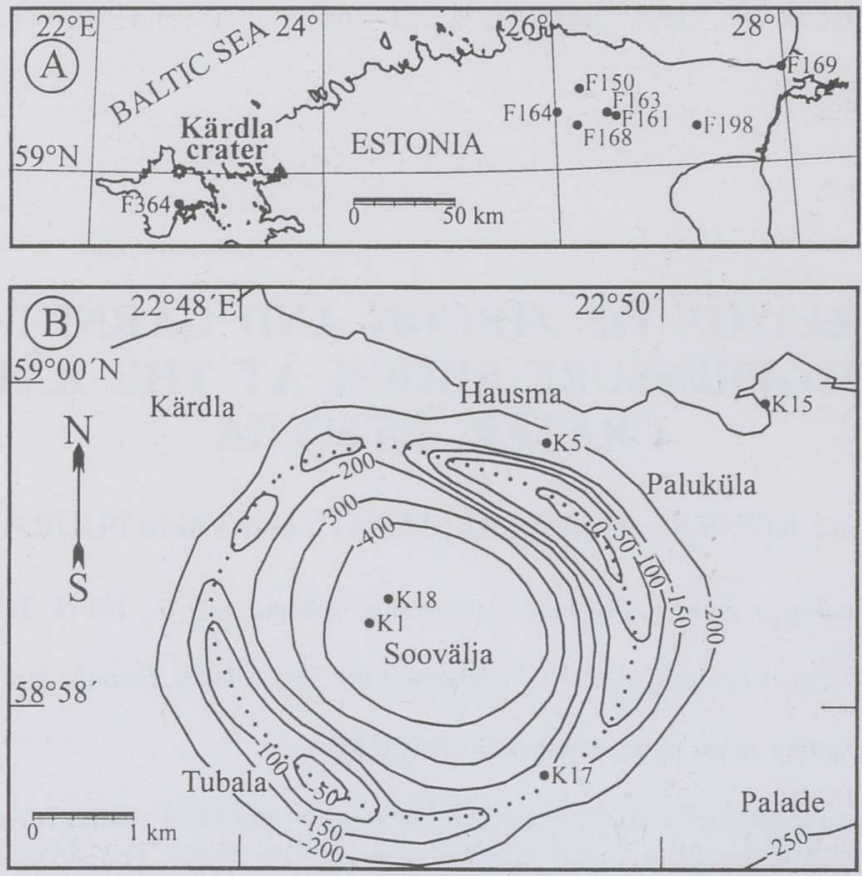

Fig. 1. (A) Location of the Kärdla crater on Hiiumaa Island, Estonia, and drill cores (F150, F161, F163, F164, F168, F169, F198, F364). (B) Topography of the fractured crystalline basement of the Kärdla buried crater area (after Puura \& Suuroja 1984) and location of drill cores (K1, K5, K15, K17, K18).

examine gradual changes of these minerals from reference rocks through the rather weakly deformed marginal parts of the crater to the most intensely shocked impactites represented by allochthonous suevitic breccias.

\section{CRATER GEOLOGY AND LITHOLOGIES}

The Kärdla crater formed about 455 million years ago in shallow shelf environments (water layer 20-50 m, Puura \& Suuroja 1992), where about $150 \mathrm{~m}$ thick Cambrian and Lower to Middle Ordovician deposits covered the Precambrian crystalline basement (Puura et al. 2000). The $500 \mathrm{~m}$ deep complex crater with a small central uplift, which formed in this composite target, penetrated into the crystalline basement to a depth of up to $400 \mathrm{~m}$. As a result of the impact, around the annular depression, a discontinuous ring wall of crystalline rocks covered by deformed sedimentary strata and breccia was formed. The impact-produced units are mostly well survived under the subsequent Middle to Upper Ordovician marine deposits. Only the ejecta layer near the uplifted ring wall was truncated by erosion in a shallow sea along the ring-shaped island chain. 


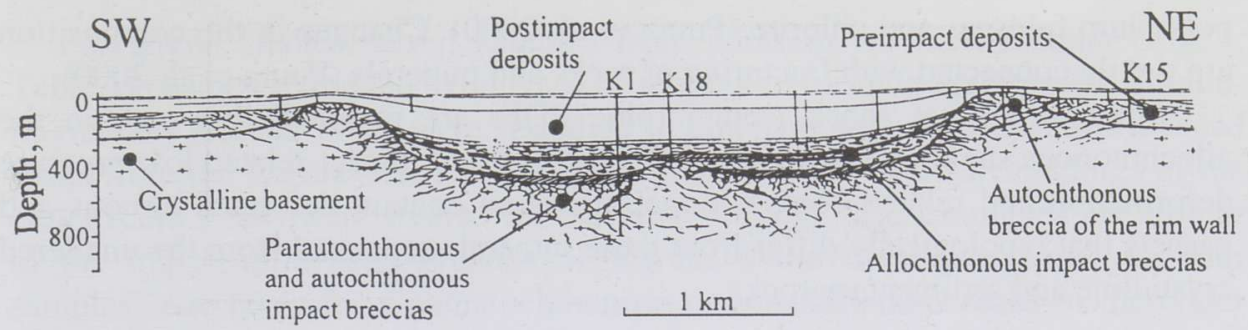

Fig. 2. Cross-section (SW-NE) of the Kärdla crater, modified after Puura et al. (2000). Drill cores $\mathrm{K} 1, \mathrm{~K} 15$, and $\mathrm{K} 18$ studied.

Principal impact-induced lithological units in the centre of the Kärdla crater are illustrated in Fig. 2. From the bottom these are as follows:

- autochthonous crystalline rock in the surroundings of the crater unaffected by the impact, fractured and occasionally brecciated in a half-sphere embracing the crater. A fractured or brecciated rock body forms the crater floor including the central uplift and rim wall. The thickness of this unit reaches some $500 \mathrm{~m}$ or even more (in the centre of the crater, down to about 1000 m under the present surface) (Plado et al. 1996; Puura et al. 2000);

- parautochthonous crystalline rock breccia unit, up to $70 \mathrm{~m}$ thick, covering the autochthonous subcrater basement and probably formed due to the crushing of the basement almost in situ, without any substantial transportation;

- allochthonous breccias in the crater that consist of fragments of both crystalline and sedimentary rocks are divided into layers of different origin (Puura \& Suuroja 1992; Puura et al. 2000);

- suevitic (indicated by rare small melt rock particles, Suuroja 1999), partly airfall layers in the crater;

- slumped breccia layers in the crater;

- resurge (tsunami) breccia layer in the crater.

Impact metamorphic phenomena such as PDFs in quartz occur only in the most impact-influenced suevitic breccia units (Suuroja 1999). Taking into consideration the intensity of PDFs and their occurrence in the allochthonous suevitic airfall breccia only, the estimated maximum shock pressure of breccia formation exceeded 10-15 GPa (Suuroja 1999), and the pressure of deformation of subcrater basement rocks was far less than $8 \mathrm{GPa}$ (Puura et al. 2000).

The fractured and brecciated crystalline rocks that are found in autochthonous, parautochthonous, and allochthonous position in the Kärdla structure show sharp geochemical anomalies. A very pronounced depletion with $\mathrm{Ca}$ and $\mathrm{Na}$ and enrichment $\mathrm{K}$ of these rocks, i.e. granitoids and amphibolites, is documented (Puura \& Suuroja 1992; Puura et al. 1996). Mineralogically, this chemical change is expressed in decomposition of plagioclase and hornblende, and formation of 
potassium feldspar and chlorite (Puura et al. 2000). Changes in the composition are tightly connected with fracturing of rocks and minerals (Puura et al. 2000).

Although distinct shock metamorphic PDFs are rare and met only in the allochthonous suevitic breccia, the rocks subjected to impact-related low-pressure deformation and related compositional alteration contain deformed zircons and garnets that typologically differ from these minerals separated from the unaltered crystalline and sedimentary rocks.

\section{MATERIAL AND LABORATORY TECHNIQUES}

Samples were obtained from the drill cores that penetrated into the subcrater parautochthonous and autochthonous breccias and fractured rocks, and withincrater allochthonous, suevitic breccias. Reference samples were taken from the granitoids similar to the crater rocks far outside and in the near surroundings of the crater (Figs. 1, 2; Table 1).

Table 1. Morphology of 0.1-0.05 mm size zircon grains in reference (1) and shocked (2-4) rocks

\begin{tabular}{|c|c|c|c|c|c|c|c|c|}
\hline \multirow[t]{2}{*}{ Rocks studied } & \multirow[t]{2}{*}{ Core } & \multirow[t]{2}{*}{ Sample } & \multirow{2}{*}{$\begin{array}{c}\text { Cracked } \\
\text { zircon, } \\
\%\end{array}$} & \multirow{2}{*}{\begin{tabular}{|c|} 
Zircon with \\
inclusions, \\
$\%$
\end{tabular}} & \multirow{2}{*}{$\begin{array}{c}\text { Zoned } \\
\text { zircon, } \\
\%\end{array}$} & \multicolumn{3}{|c|}{ Shape of zircon, $\%$} \\
\hline & & & & & & \begin{tabular}{|c|}
$\begin{array}{c}\text { Sub- } \\
\text { hedral }\end{array}$ \\
\end{tabular} & Irregular & \begin{tabular}{|c}
$\begin{array}{c}\text { Sub- } \\
\text { roun- } \\
\text { ded }\end{array}$ \\
\end{tabular} \\
\hline \multirow[t]{9}{*}{ 1. Reference granitoids } & F161 & F1613405 & \multirow[t]{2}{*}{55} & \multirow[t]{2}{*}{40} & \multirow[t]{2}{*}{10} & \multirow[t]{2}{*}{65} & \multirow[t]{2}{*}{10} & \multirow[t]{2}{*}{25} \\
\hline & F168 & F1683707 & & & & & & \\
\hline & F163 & F1633520 & 35 & 53 & 19 & 60 & 20 & 20 \\
\hline & F198 & F1983070 & \multirow[t]{2}{*}{50} & \multirow[t]{2}{*}{60} & \multirow[t]{2}{*}{5} & \multirow[t]{2}{*}{84} & \multirow[t]{2}{*}{2} & \multirow[t]{2}{*}{14} \\
\hline & F169 & F1692140 & & & & & & \\
\hline & F150 & F1502602 & \multirow[t]{2}{*}{30} & \multirow[t]{2}{*}{80} & \multirow[t]{2}{*}{2} & \multirow[t]{2}{*}{18} & \multirow[t]{2}{*}{19} & 63 \\
\hline & F164 & F1643135 & & & & & & \\
\hline & \multirow[t]{2}{*}{ F364 } & F3643112 & 45 & 60 & 3 & 48 & 22 & 30 \\
\hline & & F3643425 & 35 & 50 & 6 & 58 & 14 & 28 \\
\hline Mean value & & & 41 & 57 & 8 & 56 & 14 & 30 \\
\hline $\begin{array}{l}\text { 2. Autochthonous breccia } \\
\text { of the rim wall }\end{array}$ & K17 & K170717 & 60 & 67 & 2 & 44 & 43 & 13 \\
\hline \multirow{3}{*}{$\begin{array}{l}\text { 3. Autochthonous rocks of } \\
\text { the subcrater basement }\end{array}$} & \multirow{3}{*}{ K1 } & K18064 & 50 & 30 & 14 & 34 & 41 & 25 \\
\hline & & K17053 & 55 & 26 & 6 & 22 & 53 & 25 \\
\hline & & K16060 & 58 & 25 & 15 & 46 & 20 & 34 \\
\hline \multirow{2}{*}{$\begin{array}{l}\text { 4. Allochthonous suevitic } \\
\text { breccia }\end{array}$} & \multirow[t]{2}{*}{ K18 } & K183830 & 75 & 20 & 7 & 26 & 28 & 46 \\
\hline & & K183960 & 70 & 21 & 6 & 30 & 25 & 45 \\
\hline 2-4 Mean value & & & 61 & 31 & 8 & 34 & 35 & 31 \\
\hline
\end{tabular}

In sample numbers here and throughout this paper the last four digits show the depth of a sample in decimetres, the letter and other digits denote the number of a drill core. 
For zircon studies, seven samples from cores in northern Estonia (Fig. 1; Table 1) characterizing the main types of migmatite-forming granites and granitemigmatites (Konsa 1986) were restudied to compare with the impact-influenced rocks from the Kärdla structure. Two samples from the near surroundings of the crater (core F364) were studied for the same purpose. These samples are similar to the impact-influenced granites of Kärdla. From the crater structure, four samples were taken from parautochthonous or autochthonous rocks of the crater rim wall (one sample from core K17) and subcrater basement (three samples from core K1). Three samples were taken from allochthonous breccia from core K18 (Figs. 1,2; Table 1). Samples were studied and microphotographed in oil immersion. Selected grains of zircon were microphotographed under the scanning electron microscope (SEM).

For garnet studies, two samples from core F364 in near surroundings of the crater, two samples from the rim wall (cores K17 and K5), three samples from the autochthonous subcrater basement (core K1), one sample from the parautochthonous breccia (core K1), and three samples from the allochthonous suevitic breccia (core K18) were selected (Figs. 1, 2). Garnets from some samples taken from the clastic ejecta layer outside the NE crater rim wall have been studied previously (Kleesment et al. 1987; Puura et al. 1997).

Samples weighing $100-400 \mathrm{~g}$ were crushed down to the size of $2-3 \mathrm{~mm}$, best disintegrating the crystals but trying to save them from crushing and powdering. Fractions less than $0.01 \mathrm{~mm}$ were removed by washing. The coarser part was separated by sieving into fractions coarser than $1 \mathrm{~mm}, 1-0.5 \mathrm{~mm}, 0.5-0.25 \mathrm{~mm}$, $0.25-0.1 \mathrm{~mm}, 0.1-0.05 \mathrm{~mm}$, and $0.05-0.01 \mathrm{~mm}$ size. The three coarsest fractions were observed using the binocular microscope. The finer fractions were separated using bromoform, and the light and heavy minerals were determined in immersion liquids under a microscope in plane-polarized transmitted light.

Samples were studied in oil immersion. Sixteen garnet grains from sample K183830 were examined and photographed by the SEM Tesla-BS-340. Using the Link microanalyser, relative contents of $\mathrm{Mg}, \mathrm{Al}, \mathrm{Si}, \mathrm{Ca}, \mathrm{Ti}, \mathrm{Cr}, \mathrm{Mn}$, and $\mathrm{Fe}$ were determined semiquantitatively. The examined garnet grains were scattered in Canadian balsam, polished, and the core and the rim of each grain were measured separately.

\section{RESULTS}

\section{Zircon}

\section{Typology of zircon}

As a result of our previous systematic study of zircon selected from crystalline and sedimentary rocks outside the crater (Konsa \& Puura 1999), and present work on the impact-influenced rocks of the Kärdla crater, a number of specific typological features were determined. These features carry information on the behaviour of this mineral in rocks subjected to low-pressure deformation. For the 
study of the influence of impact processes on zircon typology, the most informative features were: (a) morphology, (b) zoning and cores, (c) fracturing, (d) inclusions, and (e) transparency (Table 1).

\section{Zircon from unshocked granites outside the crater, northern Estonian zone}

Plagiomicrocline granite (samples F1613405 and F1683707, Alutaguse Zone; Table 1; Pl. I, figs. 1,2). These samples are dominated by subhedral, or subrounded (up to 25 grains), prismatic, light brownish or colourless, cracked and inclusion-rich zircon, sometimes with cores (up to 65\%). Zoning is absent or weakly developed. This zircon is often opaque, metamict. Subrounded zircon is translucent, brownish, cracked and sometimes with cores. Irregular grains are rare.

Plagiogranite (F1633520, Alutaguse Zone; Pl. I, figs. 3, 4). Subhedral transparent or translucent zircon is abundant (up to 60\%). It is clear, sometimes with distinct zoning, inclusion-rich, lacks fracturing. The minority of zircon (up to 20\%) is subrounded, translucent, cracked, inclusion-rich. This zircon is observed also as a core within the subhedral zircons.

\section{Explanation of Plate I}

Zircon grains $(0.1-0.05 \mathrm{~mm})$ from the unshocked granites outside (figs. 1-10) and shocked granites inside (figs. 11-22) the Kärdla structure; plane-polarized transmitted light.

Fig. 1. Core F161, sample F1613405.

Fig. 2. Core F168, sample F1683707.

Figs. 3, 4. Core F163, sample F1633520.

Fig. 5. Core F198, sample F1983070.

Fig. 6. Core F169, sample F1692140.

Fig. 7. Core F150, sample F1502602.

Fig. 8. Core F164, sample F1643135.

Figs. 9, 10. Core F364, samples F3643112 and F3643425

Fig. 11. Core K17, sample K170717.

Figs. 12, 13. Core K1, sample K18064.

Figs. 14, 15. Core K1, sample K17053.

Figs. 16, 17. Core K1, sample K16060.

Figs. 18, 19. Core K18, sample K183830.

Fig. 20. Core K18, sample K183900.

Figs. 21, 22. Core K18, sample K183960. 

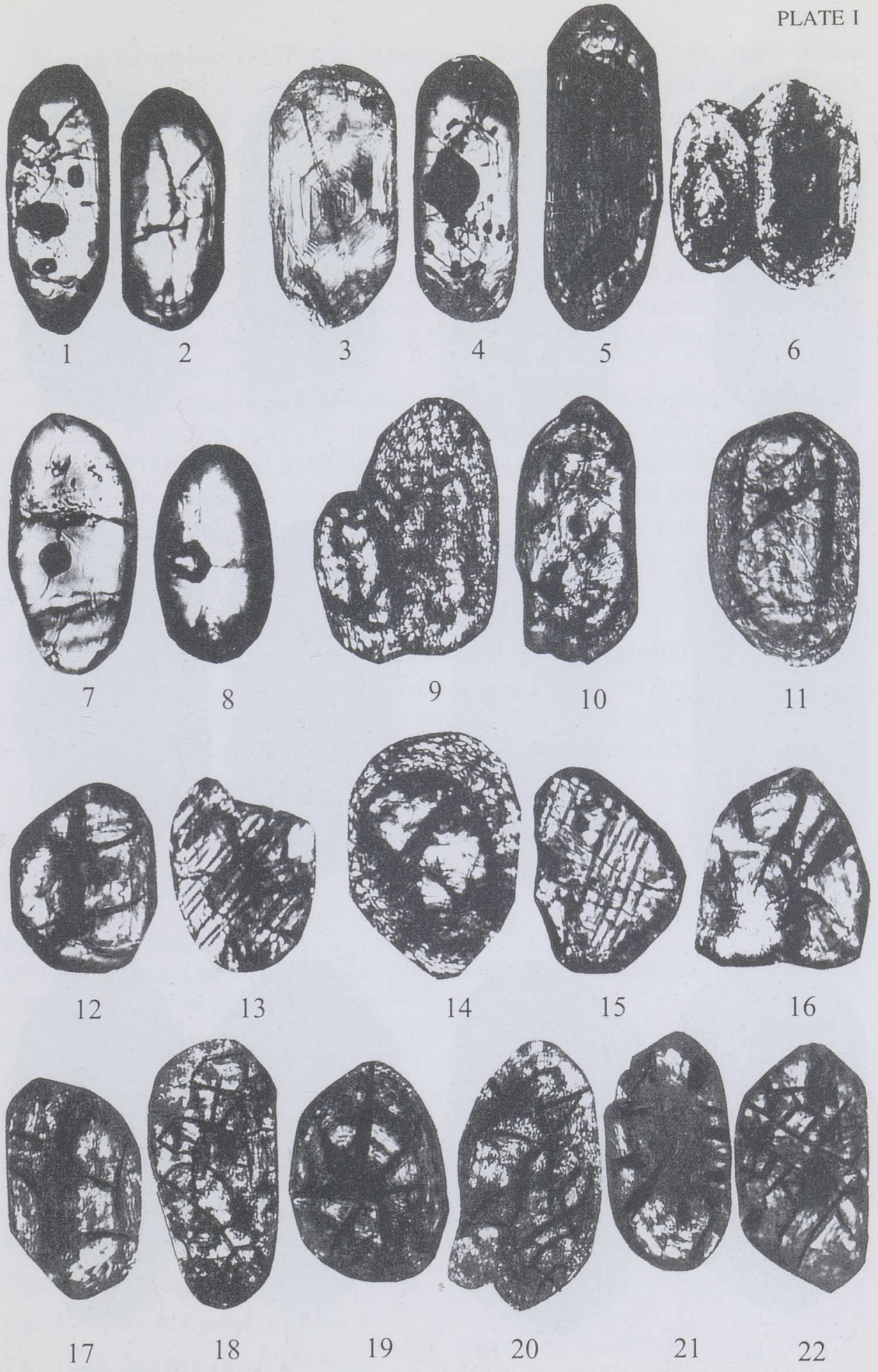
PLATE II

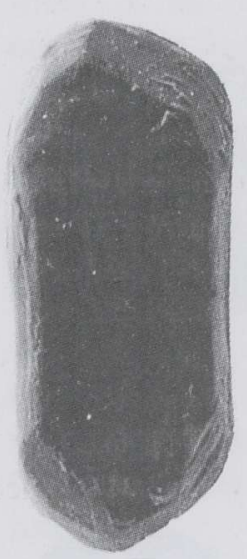

1

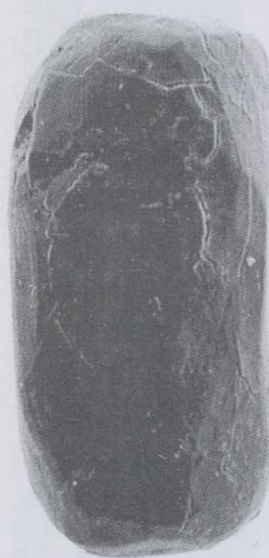

5

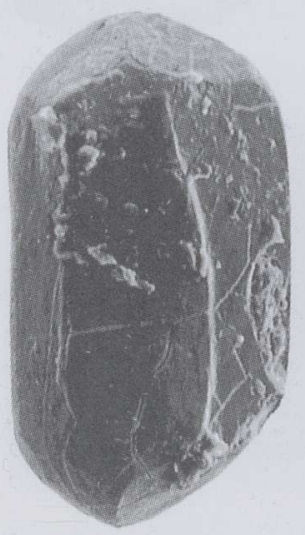

9
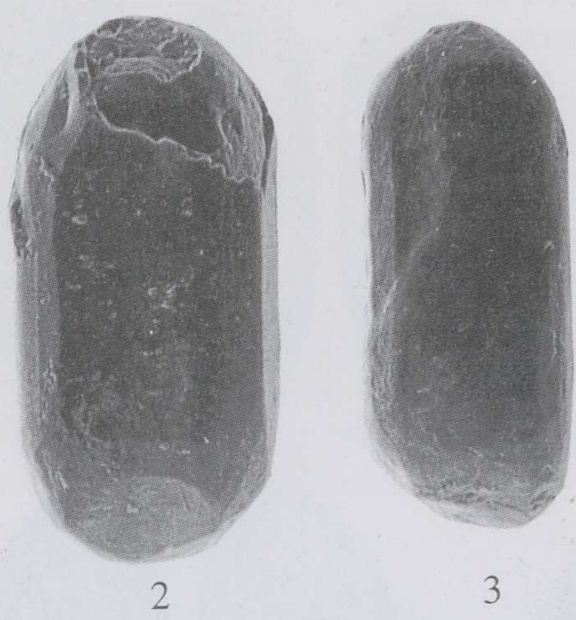

3

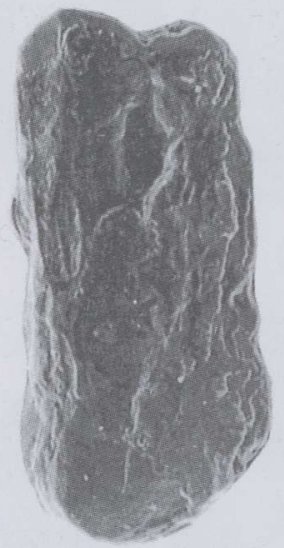

6

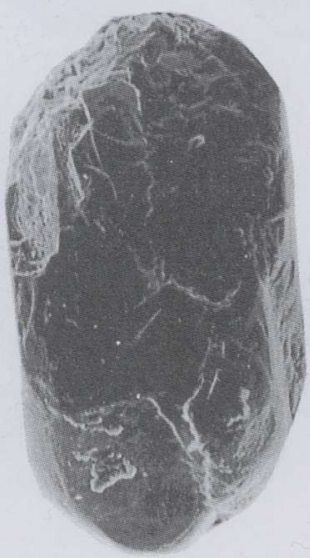

10

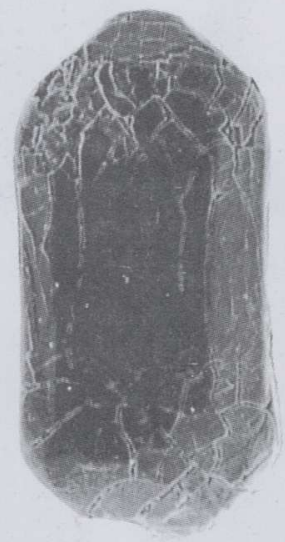

7

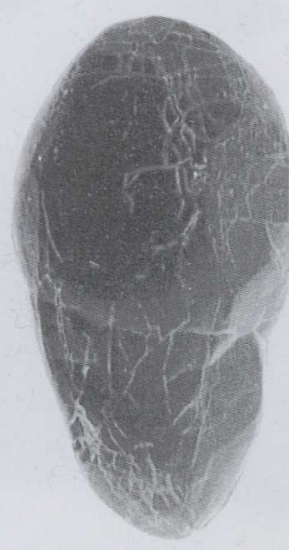

11

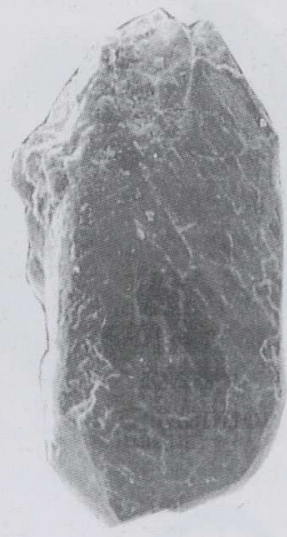

4

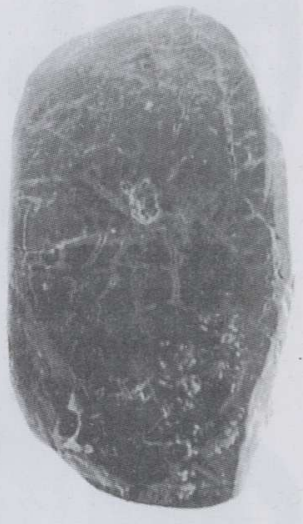

8

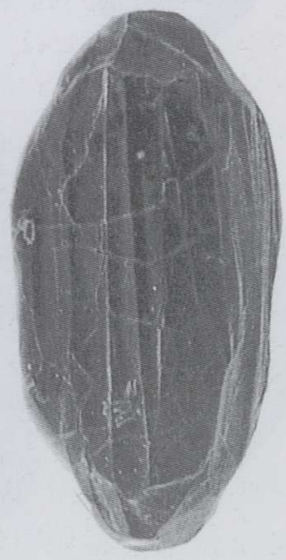

12 
Migmatite granite (F1983070, Alutaguse Zone and F1692140, Jõhvi Zone; Pl. I, figs. 5, 6; Pl. II, fig. 1). The oldest zircon (up to $14 \%$ of grains) is subrounded or rounded, translucent and metamict, inclusion-rich and cracked. Subhedral zircon (up to $84 \%$ ) is translucent or opaque (metamict), inclusion-rich, often cracked. Zoning is weakly developed. The oldest rounded zircon may occur as cores in subhedral grains. The youngest zircon generation occurs only as overgrowths on subhedral zircons.

Migmatite granite (F1502602, Alutaguse Terrane and F1643135, Tapa Block; Pl. I, figs. 7, 8). Zircon is represented by more or less rounded, transparent brownish or yellowish, weakly cracked, inclusion-rich grains. Zoning, cores, and overgrowths are missing.

Migmatite granite (from near surroundings of the Kärdla crater, F3643112 and F3643425; Pl. I, figs. 9, 10; Pl. II, fig. 2). In general, this zircon is similar to the zircons F1983070 and F1692140 (see above). Up to 30\% is subrounded, dark, metamict, rich in inclusions, rarely with zoning, more cracked than the next type of zircon. Subhedral zircon (up to 58\%) is relatively transparent or translucent, rich in inclusions, cracked. Cores of subrounded zircon, overgrowths, and twinned grains are frequent.

\section{Zircon from impact-influenced rocks in the Kärdla crater}

The results of our studies will be given in order of gradual strengthening of the shock influence. Thus we start with a sample from the rim wall (core K17) and continue from the bottom of core K1 (fractured subcrater basement), and, finally, with core K18 (allochthonous breccias).

\section{Explanation of Plate II}

SEM photomicrographs of zircon grains $(0.1-0.05 \mathrm{~mm})$ from the unshocked granites outside (figs. 1,2) and shocked granites inside (figs. 3-12) the Kärdla structure.

Fig. 1. Core F198, sample F1983070.

Fig. 2. Core F364, sample F3643112.

Fig. 3. Core K17, sample K170717.

Fig. 4. Core K1, sample K18064.

Fig. 5. Core K1, sample K17053.

Fig. 6. Core K1, sample K16060.

Figs. 7, 8. Core K18, sample K183830.

Figs. 9, 10. Core K18, sample K183900.

Figs. 11, 12. Core K18, sample K183960. 
Rim wall. Sample K170717 (Pl. I, fig. 11; Pl. II, fig. 3) was taken from the autochthonous breccia of the rim wall. Zircon occurs mostly as subhedral translucent or opaque crystals, often as irregular grains (fragments of larger crystals). Grains are often zoned, with cores and overgrowths, inclusions are survived. On the whole, fracturing of zircon is similar to surrounding rocks, however, the cores are obviously more cracked than in the surroundings. The level of impact-induced changes is minimal. In complexion with the other samples from the crater, however, these changes are detectable.

Subcrater basement. Sample K18064 (Pl. I, figs. 12, 13; Pl. II, fig. 4). Autochthonous rocks of the subcrater basement. Zircon is often zoned, with cores, translucent to opaque, occasionally turbid, subhedral to subrounded or irregular (fragments), relatively intensely fractured, widening of pre-existing cracks is remarkable. Inclusions are lacking. Striation on zircon grains surface is rare, reminding suspect weak PDFs. Although this feature cannot be interpreted as a real PDF, it is still met only in samples of the Kärdla crater and not in samples from the surrounding rocks.

Sample K17053 (Pl. I, figs. 14, 15; Pl. II, fig. 5). Autochthonous rocks of the subcrater basement. Zircon is represented by subrounded, subhedral, and often irregular (cracked fragments and aggregates) grains. Crystals are translucent to opaque, turbid, inclusion-poor. The number of cracks in zircon grains is similar to the surrounding rocks, but the fractures are stronger and larger. Irregular fracturing of the coating is observed, but not very tight. Narrowly spaced parallel striation occurs on the grain surface.

Sample K16060 (Pl. I, figs. 16, 17; Pl. II, fig. 6). Autochthonous rocks of the subcrater basement. Grains are subhedral, but often irregular, consisting of several fragments. The crystals are opaque and turbid, relatively intensely fractured, with widened fractures. The number of inclusions is remarkably less than in reference rocks. Zircon in this sample is strongly different from the background granitic rocks.

Within-crater allochthonous breccia, the suevitic unit. Sample K183830 (Pl. I, figs. 18, 19; Pl. II, figs. 7, 8). Allochthonous suevitic breccia. In this sample probably two zircon populations occur. The first zircon population is composed of mainly more or less rounded and deformed grains, with cores and overgrowths. Grains are opaque and strongly cracked. The cracks are widened, the coatings are dissected by a dense net of narrow cracks. The share of zircon with inclusions is small (20\%). The second zircon population is represented by relatively clear, transparent, mostly subhedral grains cut by open cracks. They are more inclusion-rich than the turbid zircons of the first population.

Sample K183900 (Pl. I, fig. 20; Pl. II, figs. 9, 10). Allochthonous suevitic breccia. Very few zircon grains in this sample are subhedral to rounded, brown, translucent to opaque, turbid, and cracked. Cracks are open and widened. Irregular fracturing of coatings is present.

Sample K183960 (Pl. I, figs. 21, 22; Pl. II, figs. 11, 12). Allochthonous suevitic breccia. In this sample as well two zircon populations occur. Most of 
zircons are subrounded to subhedral, also irregular aggregates of fragments. They are translucent to opaque, cracked with widened fractures in interiors and fracturing of the coating layer, mostly inclusion-poor. Minority of zircons are subhedral (to euhedral) zircon crystals, clear, transparent, sometimes with zoning, rich in inclusions.

The presence of two populations of zircons in the most intensely impacted breccia sample K183830 and to a lesser amount also in sample K183960 may suggest admixture of less impact-influenced airfall material within the mostly parautochthonous breccia material near the central uplift of the crater.

\section{Zircons in shocked and unshocked granitoids from Kärdla: a comparison}

The granitoids forming the subcrater basement and rim wall were subjected to low-pressure shock metamorphism. Rock and mineral clasts taken from the allochthonous suevitic breccias have undergone different pressure levels, because from these rock samples rare quartz grains with shock metamorphic planar deformations were found (Suuroja 1999). In a few cases, zircon separated from autochthonous subcrater fractured rocks had a parallel striation on the surface that resembled the planar features. Zircon with features of this kind has been found nowhere else in Estonia. However, in the same rocks, no planar deformations were found in quartz. All the other typomorphic features of zircon can be characterized in order to find differences between zircons from unshocked surrounding rocks and weakly shocked rocks from the Kärdla structure.

In the Kärdla structure, preshock granitoids consisted of different types of original zircons. Rounded and subrounded grains of the oldest generation, subhedral crystals and overgrowths on their surfaces were present. These types are known also in surrounding granitoids of the Estonian basement.

Fracturing is the feature that is expected to differ between the shocked and unshocked zircons. In fact, the number of fractured crystals in samples from the subcrater basement does not substantially differ from the reference rocks, being $30-40 \%$ in both. However, in allochthonous suevitic breccias the share of fractured crystals has increased to $75 \%$. The main specific feature of shocked zircons is that the fractures are remarkably widened, especially in the subcrater basement, but also in allochthonous suevitic breccias. A very specific feature of shocked zircons is an irregular set of frequent thin fractures in the coating layer of zircons. It is most intense in the allochthonous breccia, but also remarkable in the subcrater basement.

In reference rocks, inclusions occur in $50-60 \%$, in rare cases in $80 \%$ of zircon grains. In the subcrater basement, the share of grains with inclusions has decreased twofold, in allochthonous breccias even two- to threefold.

Transparent and translucent zircons, sometimes of yellowish or even brownish colour are characteristic of unshocked granitoids. In shocked rocks, the share of opaque grains has increased remarkably. Turbid crystals occur in both unshocked and shocked rocks. However, in the uppermost sample of the subcrater basement (sample K16060) and in all samples from the allochthonous suevitic breccia, the share of turbid grains exceeds $80 \%$. 


\section{Garnet}

In the basement rocks in Estonia, garnet occurs mostly as subhedral and euhedral grains, usually less than $0.5 \mathrm{~mm}$ in size. Poikiloblastic garnet crystals may reach the size of $10-30 \mathrm{~mm}$. In metamorphic rocks, elongated and subrounded grains are found. Cracked garnets occur in fault zones. Here, parallel to crack planes, mica and cordierite intergrowths are developed (Puura et al. 1983; Hölttä \& Klein 1991). In sedimentary rocks, subhedral and subrounded garnet grains are spread. Cracked crystals have not been discovered in sedimentary rocks (Kleesment \& Paap 1978, 1979).

Garnet is very rare in samples taken from the near surroundings of the crater (core F364). The grains separated are subhedral, less than $0.5 \mathrm{~mm}$ in size. Cracked crystals were not observed. Also in samples from the rim wall (K170717 and K50330), garnet is very rare and uncracked.

In the lower part of core $\mathrm{K} 1$, rare garnet crystals are not cracked either (K18064; Pl. III, fig. 1). In sample K16060 from the uppermost part of the autochthonous subcrater basement, in rare garnet crystals few cracks were found (Pl. III, fig. 2). Also in sample K15870 from the lower part of the parautochthonous breccias rare cracked garnet crystals are present.

In the samples taken from allochthonous suevitic breccias cracked garnets are frequent. In sample K183830 all the grains are cracked. Crack planes oriented in several directions are often branched and intricate (Pl. III, figs. 3, 8). Among the subhedral (Pl. III, figs. 3,4) and unhedral (PI. III, fig. 5) grains frequently irregular and splinter-shaped fragments occur.

In samples K183900 and K183960, 20-30\% of mostly subhedral garnet grains are cracked. Only one direction of cracks is characteristic (Pl. III, figs. 9, 10), although also irregular and splinter-shaped grains occur (Pl. III, figs. 11, 12).

In the sedimentary rocks, underlying the ejecta layer outside the Kärdla crater, and elsewhere in Estonia, neither cracked nor splinter-shaped garnet grains have been observed. In the redeposited ejecta layer at Kärdla (Puura et al. 1997), cracked and irregular garnet grains (Fig. 1, K15; Pl. III, figs. 13-15) are present (Kleesment et al. 1987). The splinter-shaped grains evidence fragmentation of garnet during the impact.

\section{Explanation of Plate III}

Garnet grains from the Kärdla crater area; plane-polarized transmitted light.

Fig. 1. Core K1, sample K18064, ×1000.

Fig. 2. Core K1, sample K16060, $\times 700$.

Figs. 3, 4. Core K18, sample K183830, $\times 300$.

Fig. 5. Core K18, sample K183830, $\times 350$.

Figs. 6, 7. Core K18, sample K183830, $\times 250$.

Fig. 8. Core K18, sample K183830, $\times 400$.

Figs. 9-12. Core K18, sample K183900, ×450.

Figs. 13-15. Core K15, sample K15684, ×450. 

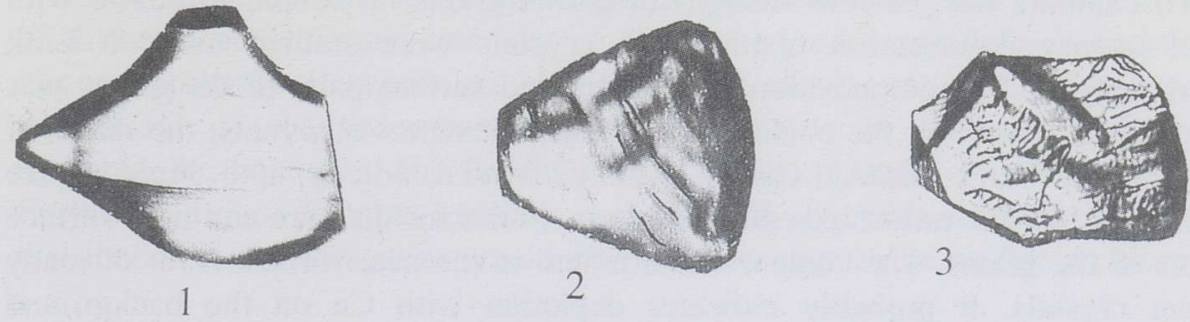

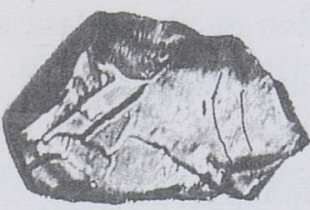

4

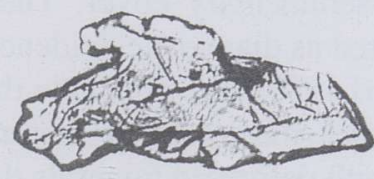

7

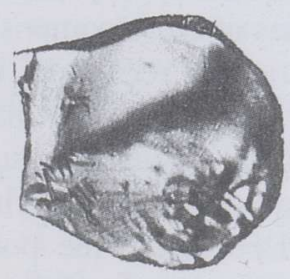

10

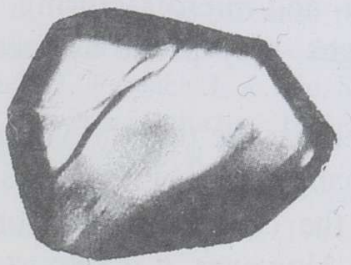

13

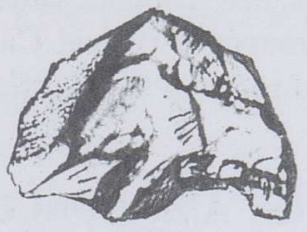

5

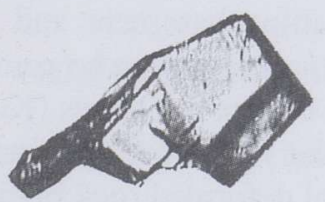

8
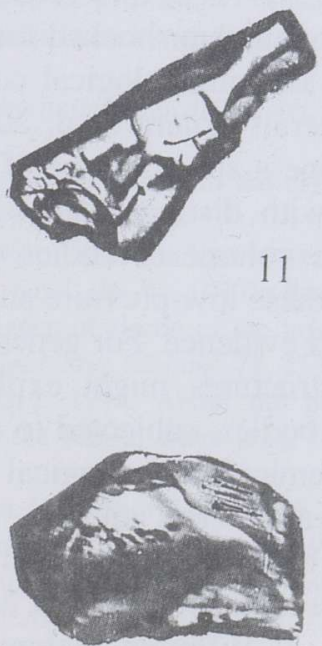

14
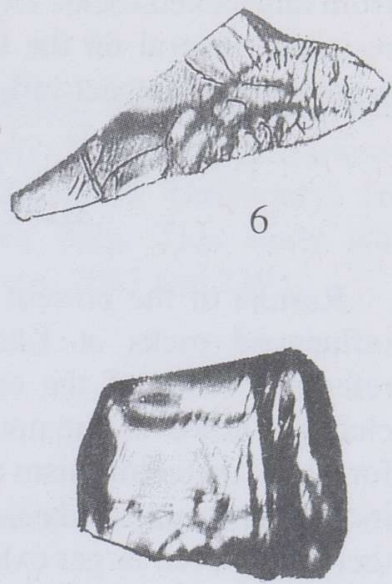

9
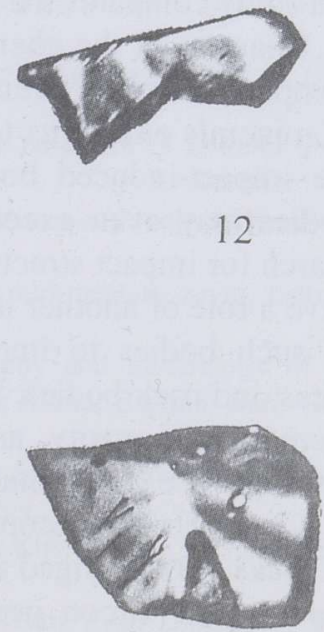

15 
To examine the possible changes of garnet grains in sample K183830 with most intense deformation features, 16 crystals were studied using a Link microanalyser. The composition of the core and surface parts of the grains was determined. Based on the contents of 8 major elements in garnets, the ratios of components $\mathrm{Ca} / \mathrm{Fe}, \mathrm{Ca} / \mathrm{Al}, \mathrm{Ca} / \mathrm{Mn}, \mathrm{Mn} / \mathrm{Al}, \mathrm{Mn} / \mathrm{Fe}, \mathrm{Mg} / \mathrm{Fe}$, and $\mathrm{Mg} / \mathrm{Al}$ were calculated. All the ratios, except $\mathrm{Ca} / \mathrm{Mn}$ are similar for the core and near-surface layers of the grains. The content of $\mathrm{Ca}$ is less in the near-surface layer of many garnet crystals. It probably indicates depletion with $\mathrm{Ca}$ on the background stability of contents of other elements. Unfortunately, there is no reference data from unshocked rocks. However, this evidence calls to further studies of this very resistant mineral on the background of typical $\mathrm{Ca}$-depletion of plagioclase and hornblende in impact-influenced rocks of the Kärdla crater (Puura et al. 2000).

\section{DISCUSSION AND CONCLUSIONS}

Results of the present study suggest that zircon and garnet from the impactinfluenced rocks at Kärdla differ remarkably from zircons separated from reference rocks of the crystalline basement and the sedimentary cover. These changes, however, are not strong enough to be considered as diagnostic evidences for shock metamorphism and impact structures (Koeberl 1997). We conclude that in impact structures beside the rocks with distinct shock metamorphic features there exist even larger external deformed rock bodies with deformed minerals that have not undergone the critical shock pressures exceeding 8-10 GPa (Puura et al. 2000). Differences between the reference rocks and minerals outside the impactinfluenced half-sphere, and impact-influenced rocks can be observed by means of the optical microscope and SEM. These differences can be statistically confirmed if a study compares the shocked and unshocked rock bodies of close composition.

Changes in the chemical and mineralogical composition of rocks and in the composition of different minerals (Puura et al. 2000), and specific deformations of minerals enable us to define a specific type of geological bodies surrounding the impact-induced bodies with distinct PDFs. The volume of these kind of bodies may even exceed the volume of bodies with PDFs. From the point of search for impact structures, these low-pressure aureoles of impact structures may have a role of another indirect evidence. For general geological studies, relevance of such bodies to impact structures might explain specific features of some areas and rock bodies. Rock bodies, subjected to macro- and microfracturing, an increase in porosity, and chemical-mineralogical changes, may prove as media favourable, e.g., for mineralization or as aquifers.

Comparing the scope of changes of zircon and garnet, we see that the volume of rocks with changed zircons is larger than that with changed garnet. Changes in typology of zircon occur in its different features. In the case of garnet, only presence or absence of fractures is somewhat indicative. However, it is important that by low-pressure shock under consideration, most of the grains are cracked and easily discriminated. 
Even in the low-pressure zone of the impact-influenced rock bodies, changes of different minerals and intensity of changes of some minerals, especially of zircon, probably depends on the value of shock pressure. Mapping the distribution of changed minerals, and the intensity of changes, could allow mapping the zoning in the distribution of shock pressure in subcrater rocks. Further studies of different minerals in the weakly shocked rock bodies, and their distribution within structures would provide new information on this problem.

\section{ACKNOWLEDGEMENTS}

We are grateful to K. Suuroja and M. Niin (Geological Survey of Estonia) who provided most of the samples for the present study. We thank G. Baranov for preparing microphotographs, V. Mikli (Tallinn Technical University) for assistance in SEM studies, and I. Puura for linguistic help. This study was supported by the Estonian Science Foundation (grants Nos. 2063 and 2191).

\section{REFERENCES}

Hölttä, P. \& Klein, V. 1991. Pt-development of granulite facies rocks in southern Estonia. Geol. Surv. Finland Spec. Pap., 12, 37-47.

Kleesment, A. \& Paap, Ü. 1978. About postdepositional changes of garnet grains. Litol. polezn. iskopaemye, 5, 135-143 (in Russian).

Kleesment, A. \& Paap, Ü. 1979. Garnet surface features in Baltic Devonian deposits. ENSV TA Toim. Geol., 28, 18-25 (in Russian).

Kleesment, A.-L., Pirrus, E., Suuroja, K. \& Tiirmaa, R. 1987. Geology of the north-eastern outer slope of the mound of the Kärdla buried crater. Proc. Acad. Sci. ESSR. Geol., 36, 131-139 (in Russian).

Koeberl, C. 1997. Impact cratering: the mineralogical and geochemical evidence. Oklahoma Geol. Surv. Circ., 100, 30-54.

Konsa, M. 1986. Typomorphic variations of zircon in the crystalline basement of Estonia. Proc. Acad. Sci. ESSR. Geol., 35, 1-9 (in Russian).

Konsa, M. 1987. Typomorphic features of zircon in basal layers of sedimentary rocks of the North Baltic. Proc. Acad. Sci. ESSR. Geol., 36, 97-103 (in Russian).

Konsa, M. \& Puura, V. 1999. Provenance of zircon of the lowermost sedimentary cover, Estonia, East-European Craton. Bull. Geol. Soc. Finland, 71, 253-273.

Koppelmaa, H., Niin, M. \& Kivisilla, J. 1996. About the petrography and mineralogy of the crystalline basement rocks in the Kärdla crater area, Hiiumaa Island, Estonia. Bull. Geol. Surv. Estonia, 6, 4-24.

Plado, J., Pesonen, L. J., Elo, S., Puura, V. \& Suuroja, K. 1996. Geophysical research on the Kärdla impact structure, Hiiumaa Island, Estonia. Meteoritics Planet. Sci., 31, 289-298.

Puura, V., Vaher, R., Klein, V., Koppelmaa, H., Niin, M., Vanamb, V. \& Kirs, J. 1983. Kristallicheskij fundament Estonii. Nauka, Moscow (in Russian).

Puura, V. \& Suuroja, K. 1984. Kärdla kraater, maapõue varjatud uunikum. Eesti Loodus, 9, 559565.

Puura, V. \& Suuroja, K. 1992. Ordovician impact crater at Kärdla, Hiiumaa Island, Estonia. Tectonophysics, 216, 143-156. 
Puura, V., Kirsimäe, K., Kivisilla, J., Plado, J., Puura, I. \& Suuroja, K. 1996. Geochemical anomalies of terrestrial compounds in nonmelted impactites at Kärdla, Estonia. Meteoritics Planet. Sci., 31, Supplement, A112-A113.

Puura, V., Suuroja, K. \& Kleesment, A. 1997. External impact-related clastic sediments, Kärdla crater, NW Estonia. In Impact and Extraterrestrial Spherules: New Tools for Global Correlation (Raukas, A., ed.), pp. 43-44. Inst. Geol., Tallinn.

Puura, V., Kärki, A., Kirs, J., Kirsimäe, K., Kleesment, A., Konsa, M., Niin, M., Plado, J., Suuroja, K. \& Suuroja, S. 2000. Impact-induced replacement of plagioclase by K-feldspar in granitoids and amphibolites at the Kärdla crater, Estonia. In Impacts and the Early Earth (Gilmour, I. \& Koeberl, C., eds.), pp. 417-445. Springer, Berlin.

Suuroja, S. 1999. Lithologies of within-crater breccias of the Kärdla Crater. Inst. Geol., Univ. Tartu (unpublished thesis, in Estonian).

\title{
NÕRGAST LÖÖKMETAMORFISMIST PÕHJUSTATUD MUUTUSED KÄRDLA KRAATRI TSIRKOONIS JA GRANAADIS
}

\author{
Mare KONSA, Anne KLEESMENT ja Väino PUURA
}

Polarisatsioon- ja skaneeriva mikroskoobi abil uuriti tsirkooni- ja granaaditerade ümberkujunemisi Kärdla meteoriidiplahvatuse madala rõhu vööndis muutunud granitoidides ning võrdluseks samu ilminguid plahvatusest mõjustamata ja muutumata granitoidides. Meteoriidiplahvatuse mõjul on tsirkooni olemasolevad lõhed tunduvalt laienenud ning terade kattekihti on tekkinud uus tihe lõhedevõrk, suurenenud on sogaste terade osakaal, suletistega terade arvukus on vähenenud. Granaaditerad on kraatri põhjas, eriti aga allohtoonses süeviitses bretšas tugevasti lõhenenud. Tsirkooni ja granaadi muutuste aste peegeldab meteoriidiplahvatuse toimel kivimitele mõjunud rõhu suurust.

\section{ИЗМЕНЕНИЯ ЗЕРЕН ЦИРКОНА И ГРАНАТА ПОД ВЛИЯНИЕМ СЛАБОГО ИМПАКТ-МЕТАМОРФИЗМА В КЯРДЛАСКОМ КРАТЕРЕ}

\author{
Маре КОНСА, Анне КЛЕЕСМЕНТ и Вяйно ПУУРА
}

С помощью поляризационного и сканирующего микроскопов исследованы преобразования зерен циркона и граната в породах, находившихся при метеоритном взрыве в зоне низкого давления, а также в неизмененных гранитоидах. Под воздействием метеоритного взрыва первоначальные трещины в цирконовых зернах заметно расширились, покровный слой зерен покрылся новой сетью трещин, число загрязненных зерен увеличилось, количество зерен с включениями уменьшилось. Зерна граната на дне кратера и, особенно, в аллохтонной сиевитовой брекчии подверглись сильному растрескиванию. Изменения характера зерен циркона и граната отражают степень давления при метеоритном взрыве. 